\title{
A stakeholder elmélet és megjelenése az európai államok társasági jogában
}

\section{Stakeholder Theory and Its Appearance in Company Law in Various European States}

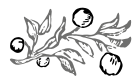

\section{Összefoglalás}

Az ezredforduló táján uralkodónak tûnt azon megközelítés, mely szerint a tôzsdén jegyzett részvénytársaságok múködésének célját a részvényesi érdekeknek való megfelelés, a profit növelése jelenti. Azonban újra megjelent, és az elmúlt évtizedben némiképp megerôsödött azon álláspont is, mely összetettebb célt tulajdonít a társaságok múködésének, és az érdekeltek szélesebb körének érdekeit javasolja figyelembe venni. Jelen tanulmány erre a társasági jogi megközelítésre törekszik példát szolgáltatni az Európai Unió egyes tagállamainak társasági jogi berendezkedéséból. Ezzel párhuzamosan ígéretesnek látja, hogy ezen államok gazdasága és társadalmi jóléte is kedvezô képet mutat.

Journal of Economic Literature (JEL) kódok: G34, K20, K29

Kulcsszavak: stakeholder elmélet, társaságirányítás, munkavállalói képviselet

\section{Summary}

At the turn of the millennium, the prevailing approach seemed to be that the purpose of listed corporations was to meet shareholder requirements and to increase profit. However, an alternative approach that re-emerged and gained ground in the past

Dr. Halász Vendel PhD, óraadó, Pécsi Tudományegyetem Állam- és Jogtudományi Kar (halasz.vendel@gmail.com). 
Halász Vendel: A stakeholder elmélet és megjelenése az európai államok...

decade assigns a more complex purpose to corporate activity, and suggests that the interests of a wider scope of stakeholders should be taken into account. This article provides examples of this approach from the company law of a few Member States of the European Union. Simultaneously, it is found to be promising that the economy and social welfare of these countries give a favourable view.

Journal of Economic Literature (JEL) codes: G34, K20, K29

Keywords: stakeholder theory, corporate governance, employee representation

A RÉSZVÉNYESi ÉRDEKEK PRIMÁTUSA A 21 . SZÁZAD HAJNALÁN

Az ezredfordulót követôen nagy lendülettel alakult az az újfajta és minden eddiginél összetettebb gazdasági rendszer, melyet globális kapitalizmusnak nevezhetünk. E gazdasági struktúra kapcsán fontos szót ejteni a részvényesi érdekek elsôdlegességét valló elméletról (shareholder elmélet). Az elmélet azon alapul, hogy a társaság tevékenységének elsôdleges célja, és éppen ezért a vállalatot irányító vezetôk elsôdleges felelôssége, illetve a társasági jog elsôdleges feladata a részvényesek befektetéseire jutó hozam maximalizálása (Millon, 2013:191). Tehát a részvényesi érdekek elsôdlegességét hangsúlyozó elmélet alapján a vállalatok vezetôi csak a társaság részvénytulajdonosai érdekében hozhatják meg döntéseiket. A részvényesi érdekek elsôdlegessége visszatükrözôdik abban az axiómában, hogy a társaság egyetlen célja a profit maximalizálása, illetve hogy a menedzsment célja a részvényesi jólét maximalizálása (SpragueLyttle, 2010:3, 4-5). Az elmélet elfogadottságát jól szemlélteti Reinier Kraakman és Henry Hansmann professzorok 2001-ben megjelent The End of History for Corporate Law címú tanulmánya. Ebben a szerzôk úgy fogalmaztak: az akadémiai, az üzleti és a kormányzati elit egyetértett abban (a vezetô államokban), hogy a társaság feletti végsô irányításnak a részvényesi osztály kezében kell lennie. A társaság menedzsereit azzal a kötelezettséggel kell megbízni, hogy a társaságot a részvényesei érdekeinek megfelelóen irányítsák. Szintén kiemelték, hogy a tôzsdei kereskedelembe bevezetett részvénytársaság papírjainak piaci ára a részvényesi érdekek elsôdleges mércéje (HansmannKraakman, 2001:439-468, 440-441; Stout, 2013:1177; Ireland, 2005:49). Angol-amerikai nézópontból érvelve Kraakman és Hansmann úgy vélte, hogy az ehhez képest alternatívát jelentô társaságirányítási modelleket (melyeket menedzsmentorientált, munkaorientált és államorientált modellként jelöltek meg) már kipróbálták, és azok nem váltak be (Liao, 2012:191-192)

A globális kapitalizmus gazdasági rendszerében az egész világot átszövố nagyvállalatok és ellátási láncok, a tơkebefektetések akadálytalan és valós idejú áramlása, a befektetésekhez elengedhetetlen információk minden eddiginél gyorsabb hozzáférhetôvé válása számos új és - legalábbis elsô látásra - nagyszerú lehetôséget tartogattak. A vállalatok számára lehetôvé vált, hogy ezek megragadásával befektetőik számára még magasabb profitot tudjanak biztosítani, sốt ez a globális versenyben alapvetô elvá- 
rássá is vált. Ez pedig mérvadó közgazdasági álláspontok szerint egyúttal a társadalom javára is válik. E megközelítés alapját adják például a Nobel-díjas amerikai közgazdásznak, Milton Friedmannek ${ }^{1}$ 1970-ben a New York Times hasábjain megjelent esszéjében olvasható gondolatai. Ebben úgy érvelt, hogy mivel a társaság részvényesei az üzlet tulajdonosai, ezért a vállalatnak az egyetlen társadalmi felelôssége a profitjának növelése (Friedman, 1970; Stout, 2002:1190-1192). A jog az Egyesült Államokban azt a bizalmi kötelezettséget ruházza az igazgatókra, hogy a részvényesek legjobb érdekében járjanak el. Mindenki más pedig - idesorolva a munkavállalókat, hitelezóket és fogyasztókat - harmadik (tehát kívülálló) szereplônek tekinthetô, aki a társasággal szerzôdéses kapcsolatba lép. A kölcsönösen elônyös szerződéseken mindenki nyer, míg a társadalom a társaság által teremtett lehetôségekbôl profitál (Velasco, 2010:898-899).

Ugyanakkor napjainkra ezt az optimista és minden bizonnyal jóhiszemú megközelítést számos kétség árnyékolta be. Sorra látnak napvilágot a globális társadalmi, vagyoni egyenlôtlenségek erősödésérôl szóló elemzések - elég, ha e tekintetben Thomas Piketty ${ }^{2}$ nagy hatású munkájára gondolunk (Piketty, 2015) -, illetve a felelôtlen gazdasági magatartás környezeti hatásaira figyelmeztetô szakértői jóslatok (például Jowit, 2010; HVG.hu, 2017). Tisztán pénzügyi megközelítést alkalmazva nem mehetünk el azon tény mellett sem, hogy az ezredforduló óta két igen jelentôs tôzsdei válságot is megfigyelhettünk (lásd a dot.com és a subprime válságot), melyból ez utóbbi elhúzódó globális pénzügyi-gazdasági krízist is eredményezett (Kecskés, 2011).

Éppen ezért a részvényesi érdekek elsôdlegességét valló elmélet helyességével, illetve különösen társadalmi hasznosságával kapcsolatban aggályok merülnek fel. A részvényesi érdekek fontossága mellett egyre többen jutnak el arra a felismerésre, hogy nem csupán a részvényesek járulnak hozzá egy társaság tevékenységéhez, és nem csupán ôket érinti egy társaság tevékenysége. A tơzsdei részvénytársaságok ügyei ugyanis olyan széles közérdeklôdésre tartanak számot, és olyan sokak életére és érdekeire vannak kihatással, hogy egy ilyen társaságot már nem lehet kizárólagosan a részvényesek javára irányítani (Keay, 2010:252).

Az egyéb érdekeltek érdekeinek figyelembevétele ugyanakkor nem teljesen új elképzelés, komoly hagyományai vannak a társasági jogban és a társaságirányításban mind az Egyesült Államokban, mind az Európai Unióban. Például az Egyesült Államokban a társaságok eredetileg azáltal jöttek létre, hogy az államok megadták számukra az ún. társasági chartát. A bejegyzéssel, jogi személlyé válással járó különleges előnyökért cserébe a korai társaságok a köz számára hasznos szolgálat ${ }^{3}$ teljesítését ajánlották fel (Wallman, 1991:166). ${ }^{4}$ Ahogy azt John Marshall ${ }^{5}$ bíró megfogalmazta a Trustees of Dartmouth College v. Woodward ügyben: a célok, melyekért egy társaságot létrehoznak, általánosan azok, amelyeket a kormányzat elő kíván mozdítani. Ezeket hasznosnak tekintették az országnak... (Wallman, 1991:166). A 19. század vége felé az államok a társasági bejegyzést (jogi személlyé alakulást) szabályozó és általánossá tevô törvényeket fogadtak el, melyek viszonylagosan egyszerúvé tették a társaságok bejegyzését. Az államoknak a társaságok bejegyzésének előmozdítására irányuló törekvése abból a remélt előnyból fakadt, melyet a társaságok nyújthattak a társadalomnak. Azért biztosítottak korlátozott felelôsséget a részvényeseknek, és „örök életet” a társa- 
Halász Vendel: A stakeholder elmélet és megjelenése az európai államok...

ságok számára, mert reményük szerint a társadalom hasznát látja a társasági növekedés és életképesség ösztönzésének. A társadalmi hasznok előmozdításában megnyilvánuló érdeket jelölhetjük meg Steven Wallman ${ }^{6}$ megfigyelése szerint, mely ösztönzi a jogot, hogy különleges egyéni előnyöket adományozzon a befektetőknek és a társaságoknak (Wallman, 1991:166-167).

A tanulmány áttekinti az egyéb érdekeltek érdekeinek figyelembevételét hangsúlyozó elméletet, illetve annak megjelenését a társasági jog bizonyos aspektusaiban az Európai Unió egyes tagállamaiban, és ilyen társasági jogi aspektusként vizsgálja a vállalati vezetôk magatartására irányadó szabályokat, illetve a munkavállalói képviselet intézményét.

\section{AZ EGYÉB ÉRDEKELTEK ÉRDEKEINEK FIGYELEMBEVÉTELÉT HANGSÚlYOZÓ ELMÉLET（STAKEHOLDER ELMÉLET）ALAPJAI}

Az egyéb érdekeltek érdekeinek figyelembevételével kapcsolatos modern nézópont komolyan alapoz Edward Freeman ${ }^{7}$ professzor munkásságára. A professzor kifejtette az egyéb érdekeltek érdekeinek gazdasági jogi és felelôs társaságirányítási szabályozásba való beépítésével járó elônyöket. Az elmélet követôi amellett érvelnek, hogy a vállalatok vezetôi nem pusztán a részvényesek „ügynökei”, és céljukat nem szabad kizárólag a profit maximalizálására korlátozni. Ellenben a vállalatok igazgatóinak közvetítőként kell fellépniük a különbözô érdekeltek irányába, és feleloos döntést kell hozniuk a vállalat által megtermelt többlet különbözô érdekeltek közötti elosztásáról (Rahim, 2011:304-305). Fontos kérdés annak meghatározása, hogy egy társaság tevékenységéhez kapcsolódóan kiket tekintünk érdekelteknek. Freeman úgy határozta meg egy szervezetben az (egyéb) érdekeltek (azaz stakeholderek) körét, mint bármely olyan csoportot vagy személyt, aki befolyásolhatja a szervezet céljainak elérését, vagy akit befolyásolhat e célok elérése. Freeman professzor ezen meghatározása és az egyéb érdekeltekkel kapcsolatos nézópontja az alapját jelenti az egyéb érdekeltek érdekeinek figyelembevételét hangsúlyozó ún. stakeholder elméletnek. Definíciójáról megállapíthatjuk, hogy az meglehetôsen tágan határozza meg az érdekeltek körét. Ugyanakkor az elmélet fejlốdése során Freeman definícióját az érdekeltek körének meghatározása tekintetében továbbgondolták. Ennek során keletkeztek szúkebb és némiképp tágabb megközelítések is. Egy jól körülhatárolt megközelítést olvashatunk Max B. Clarkson ${ }^{8}$ professzor tollából. Megfogalmazása szerint az érdekelteket úgy határozhatjuk meg, mint önkéntes, illetve önkéntelen kockázatvállalókat. Az önkéntes kockázatvállalók azon okból viselnek bizonyos kockázatot, mert tôkét (ideértve a humán és a pénzügyi tơkét) vagy valami értékeset fektettek egy társaságba. Az önkéntelen (tehát nem önkéntes) érdekeltek pedig egy társaság tevékenységéból adódóan vannak kockázatnak kitéve. Ugyanakkor e kockázati elem nélkül nincsen érdekeltség. Ez a megközelítés bevezeti a definícióba a kockázati elemet, és leszúkíti az érdekeltek körét tulajdonképpen a legitim igényekkel rendelkezôkre (Zhao, 2014:6).

Archie B. Carroll ${ }^{9}$ professzor pedig szélesebb perspektívából közelíti meg az érdekeltek körét, mely véleményem szerint hasonlóságot mutat Freeman professzor 
definíciójával. Álláspontja szerint érdekeltnek tekinthetô bármely olyan csoport vagy személy, amellyel vagy akikkel egy szervezet kölcsönhatásban van, továbbá azon személy vagy csoport is, aki/amely befolyásolhatja vagy akit befolyásolhat a szervezet tevékenysége, döntései, stratégiái, gyakorlatai vagy célkitúzései. Ez alapján egy társaságban érdekeltek lehetnek a munkavállalók, a fogyasztók, a tulajdonosok, a versenytársak, a kormányzat és a civil társadalom szervezetei (Rahim, 2011:306-307; Zhao, 2014:5). Robert Gray ${ }^{10}$ professzor és szerzôtársai pedig még inkább kiterjesztették az érdekeltek körét, és idesorolták az eljövendô generációkat és a nem emberi élólényeket is (Rahim, 2011:307; Gray-Owen-Adams, 1996).

A stakeholder elmélet megközelítésében a gazdasági társaságok kollektív vállalkozások. Ezek pedig különbözó érdekeltek befektetéseire építenek, akik hozzájárulnak a cég sikeréhez. A befektetés szót jelen esetben tágan indokolt értelmezni: egyrészt egy gazdasági társaságnak szüksége van a magánszemélyek és intézményi befektetôk által befektetett tőkére, tehát pénzre. Ez érkezhet akár részvénybefektetésként, akár hitel formájában. Szintén szüksége van olyan személyekre, akik munkájukat, intellektusukat, tapasztalatukat, tudásukat és figyelmüket a társaság szolgálatába állítják, és munkavállalóként vagy menedzserként múködnek közre a társaság sikerében. A helyi közösségekre pedig a társaság múködéséhez szükséges megfelelô háttér (például infrastruktúra, oktatás stb.) biztosításában hárul fontos szerep (Greenfield, 2008a:1043). Ez a szemlélet érhetô tetten a társaság csoportteljesítmény-elmélet (team production theory) által leírt megközelítésében. Az elmélet alapgondolata annak felismerése, hogy a társaság tevékenysége gyakran számos különbözó csoporttól kíván meg ráfordítást. A részvényesek önmagukban nem képesek egy társaság felépítésére, múködtetésére. Szükség van ehhez hitelezókre, munkavállalókra, menedzserekre és gyakran még a helyi közösségekre is, akiknek mind hozzá kell járulniuk a társaság boldogulásához. Fontos kérdésként merülhet fel, hogy miért is vállalják e csoportok a hozzájárulást a társaság sikeréhez? Egyrészt nyilvánvalóan számítanak arra, hogy erőfeszítéseikért explicit szerzôdéseik alapján kárpótolják. Például a munkavállalók - legalábbis részben - azért dolgoznak, mert ez alapján munkabérre jogosultak. Mindazonáltal a munkaviszonyokkal foglalkozó közgazdászok régóta kiemelik, hogy ebben ezen túlmutató szempontok is szerepet játszanak. Egy komplex és bizonytalan világban a nem részvényesi csoportok gyakran hagyatkoznak az implicit, „beleértett” szerződésekre is. Például az alacsonyabb beosztású vezetôk vagy munkavállalók ez alapján arra számítanak, hogy amennyiben jól dolgoznak, és lojálisak maradnak a céghez, akkor a társaság jó teljesítménye esetén a szerzôdésükben kifejezetten rögzített fizetésen túlmutató előnyben is részesülnek. Így ebben az esetben számítanak például fizetésemelésre (és/vagy jutalmazásra), munkabiztonságra és az elóléptetés lehetôségére (Stout, 2002:1195-1196).

A különbözó érdekeltek szerepének elismerésével párhuzamosan a stakeholder elmélet megkérdôjelezi a Milton Friedman által is hangoztatott azon elképzelést, mely szerint a vállalat igazgatóinak kötelezettsége, hogy a vállalat üzleti tevékenységét a részvényesek óhajának megfelelóen vezessék. Ezt az óhajt pedig általánosan úgy lehetne összefoglalni, hogy „annyi pénzt csináljanak, amennyit csak lehetséges” (Friedman, 
1970:32; Greenfield, 2008b:8). A fenti megközelítés alapján az egyéb érdekeltek érdekeit csak akkor lehetne és olyan mértékben figyelembe venni, míg az előmozdítja a részvényesi érdek érvényesülését (illetve, amilyen mértékben ezen érdekeltek megfelelố piaci erôvel rendelkeznek ahhoz, hogy rávegyék a társaságot érdekeik figyelembevételére) (Greenfield, 2008b:8). Ugyanakkor az egyéb érdekeltek érdekeit figyelembe vevô elmélet alapján az igazgatók felé követelményként fogalmazódik meg, hogy tekintetbe vegyék a társasághoz kapcsolódó egyéb érdekeltek érdekeit a részvényesi érdek(ek)en kívül. Így az igazgatóknak a társaságot nem pusztán a részvényesek értéknövekedésének érdekében kell vezetniük, hanem érdekeltek sokaságának figyelembevételével, akik hatással tudnak lenni a társaság tevékenységére, illetve akikre hatással lehet a társaság tevékenysége. Ezen érdekeltek között természetesen a részvényesek is szerepelnek (Zhao, 2014:2). Ez a szemlélet világosan tetten érhetô a társasági értékek meghatározása és az üzleti etika területén úttörô munkásságot folytató Clarkson professzor nevét órzó elvekben. A Clarkson-elvek alapján például a vállalatok vezetőinek (menedzsereinek) el kell ismerniük és aktívan figyelemmel kell kísérniük minden legitim érdekelt megfontolásait, és érdekeiket megfelelően figyelembe kell venniük a döntéshozatal és múködés során. A vállalatok vezetôinek (menedzsereinek) meg kell hallgatniuk az érdekelteket, és nyitott kommunikációt kell folytatniuk az érdekeltekkel az ô megfontolásaikról és közremúködésükról, illetve azokról a kockázatokról, melyet a vállalatban való részvételük miatt feltételeznek. A vállalat vezetőinek (menedzsereinek) szintén fel kell ismerniük az erőfeszítések és jutalmak összefüggését az érdekeltek között, és törekedniük kell arra, hogy a társasági tevékenység elônyeinek és terheinek tisztességes elosztását valósítsák meg közöttük, tekintetbe véve a rájuk nehezedô kockázatokat és kitettséget.

Az egyéb érdekeltek érdekeit figyelembe vevô elmélet alapján a legfontosabb ilyen egyéb érdekeltek a munkavállalók, a hitelezôk, a beszállítók, a fogyasztók és a - vállalat múködésével érintett - helyi közösségek (Zhao, 2014:9-16). Megjelenhet még figyelembe vehetô érdekként az adott állam, nemzet gazdasága is, illetve ezzel párhuzamosan a közérdek (Halász, 2015:19-24; Kecskés, 2010:74-75; Kecskés, 2008:254).

A stakeholder elmélet alapján így a részvényesek csoportja csupán egy azon sok versengô és különbözô csoport közül, melyeknek érdekeltsége van egy társaság tevékenységében. A stakeholder elmélet továbbá általános értelemben azon az elképzelésen alapul, hogy a társaság életében szerepet játszó minden közremúködô bevonása társadalmi, gazdasági és politikai szempontból - egyaránt értékes. Az elmélet ugyanis minden közremúködő teljes lehetôségeit elômozdítani törekszik. Az ideálja szerint az összes érdekelt fél együtt dolgozik a közös célért, és részt kapnak a megosztásra kerülő haszonból, beilleszkedve a társaság üzleti projektjébe. Mindenkinek, aki fontos erőforrásokkal járul hozzá a társaság múködéséhez, részesednie kell az eredményból. Így a társaság nem csupán a részvényeseknek való értékteremtés érdekében dolgozik. A stakeholder elmélet ugyanis ragaszkodik ahhoz az elképzeléshez, hogy a társaságok a minden érdekelt számára való értékteremtés érdekében tevékenykednek. Az igazgatói szerepet pedig a mediátori szerepkörhöz látja hasonlatosnak, ugyanis ók közvetítenek a különbözó érdekeltek között (Keay, 2010:255-257). 
A stakeholder elmélet fontos pozitívuma, hogy összhangba törekszik hozni a gazdasági és az etikai szempontokat. Ennek során pedig a bizalom és a méltányosság értékeit hangsúlyozza. A fent kifejtettek ugyanakkor már előrevetítik a gyengeségeit is. Így nehéz például meghatározni, hogy egy társaság esetében ténylegesen kiket is kell érdekelteknek tekinteni. Ezt követôen pedig az elmélet nem ad útmutatást arra vonatkozóan, hogy az igazgatóknak hogyan kellene ezen érdekeltek nagyban különbözó érdekeit kiegyensúlyozni. Szintén kérdéses, hogy milyen eszközöket lehetne biztosítani a részvényesek körén túlmutató érdekelteknek érdekeik érvényesítésére (vagyis hogy miként lehetne biztosítani az elmélet gyakorlati alkalmazását) (Keay, 2010:298-299). Szintén nagyon fontos aggály merül fel azzal kapcsolatban, hogy bár az elmélet megoldja a részvényesi opportunizmus problémáját, egy még ennél is súlyosabb problémát hívhat életre: az egyéb érdekeltek opportunista hozzáállását. Ez pedig ahhoz vezethet, hogy a társaságok számára a tôke költsége növekszik, ugyanis a befektetôk törekednének védeni befektetésüket az egyéb érdekeltek részéról tapasztalható járadékvadászattól (Keay, 2010:299).

Tibor R. Machan ${ }^{11}$ professzor pedig a szabadpiaci kapitalista gazdasági berendezkedés természetét látta veszélyeztetve a stakeholder elmélet által, mely szerinte burkoltan a világszinten már elvetett szocialista gazdasági berendezkedés irányába mutat. A professzor álláspontja szerint, miután (a szocialista gazdasági berendezkedéssel kapcsolatos) nagy kísérlet véget ért (melyben a kormányzat tulajdonában állt a termelési eszközök meghatározó része, a kormányzat adminisztrálta ezt, és ennek a politikai gazdaságtani berendezkedésnek számtalan kudarca volt az egész földön), a „szocializmus" kifejezést elhagyták. Helyette itt van a stakeholder elmélet, melynek ugyanaz lesz a kimenetele, mint a szocializmusnak volt. Ez pedig az, hogy aláaknázza az egyének jogát, hogy allokálják vagyonukat, és ezt a választást politikusok és bürokraták kezébe adja (Machan, 2017:11-12).

A STAKEHOLder ELMÉlet MEgJelenéSE A VÁllalati VEZETók TEVÉKENYSÉGÉRE IRÁNYADÓ SZABÁLYOKBAN AZ EURÓPAI UNIÓBAN

Az európai vállalati vezetôk tevékenységére irányadó szabályok kapcsán fontos útmutatást nyerhetünk az Európai Bizottság részére készített tanulmányból (Study on Directors Duties and Liability). Ez alapján a jog az igazgatók tevékenységével szembeni magatartási elvárásait gyakran a „társaság érdekére”, „társaság érdekeire” hivatkozással határozza meg. Ahol az igazgatók kötelezettségeit a társasággal szemben fogalmazzák meg (az igazgatóknak lojalitási kötelezettségük a társaság felé áll fenn), ez a kötelezettség csak abban az esetben és olyan mértékben értelmezhető, ha világos megállapodás van azon jogilag releváns érdekekre vonatkozóan, melyeket az igazgatóknak oltalmazniuk kell. Másodsorban (és ehhez kapcsolódóan) a „társaság érdeke”, „társaság érdekei” koncepció szintén fontos tényezốt jelent a vállalati vezetôk, vállalati menedzserek szerepének alakításában. Ahol a „társaság érdekei” oly módon kerültek meghatározásra, mely esetben az több érdekeltet (constituency) foglal magában, akkor a menedzseri szereppel szükségszerúen együtt jár ezen érdekek kiegyensúlyozása. Annak mértéke, 
Halász Vendel: A stakeholder elmélet és megjelenése az európai államok...

ameddig ez a „kiegyensúlyozási tevékenység” elvárt vagy éppen megengedett a vállalati menedzserek részére, szintén befolyásolja annak a menedzseri diszkréciónak a mértékét, melyet egy jogrendszer biztosít számukra (Study on Directors Duties and Liability, 2013:74). Szintén fontos kiemelni, hogy a társaságok mint jogi személyek csak a jog világában léteznek. Így bármilyen kérdés a „társaság érdekére” vonatkozóan, lényegében szükségszerúen a jog tartalmát érintô kérdés (Study on Directors Duties and Liability, 2013:74). Így érdemes megvizsgálni a „társaság érdekéről” kialakított nézốpontokat, meghatározásokat, és elemezni a „társaság érdekének” jelentéstartalmát az Európai Unió egyes tagállamaiban. Ezzel lehet ugyanis feltárni a vállalati vezetốk tevékenységével kapcsolatban irányadó elvárásokat. Mivel uniós szabályozás nem érinti ezt a területet (az uniós jogalkotás társasági jogi irányelvben vagy más jogforrásban nem foglalt állást e kérdésben), ezért a tagállami jog elemzésétốl várható eredmény. Segítséget ehhez a London School of Economics által az Európai Bizottság felkérésére 2013-ban elkészített, az uniós tagállamokban az igazgatók kötelezettségeit és felelôsségét vizsgáló tanulmány jelent. Ebben külön táblázatban (Study on Directors Duties and Liability, 2013:66-74) vizsgálták meg, hogy beletartoznak-e a hitelezôi és munkavállalói érdekek (illetve az „egyéb érdekeltek” érdeke) a „társaság érdekének” jelentéstartalmába, illetve hogy mi az általános meghatározása a „társaság érdekének” egy adott állam esetében (Study on Directors Duties and Liability, 2013:66-74). Ez alapján megállapítható, hogy az Európai Unióban az érdekeltek szélesebb körét helyezi középpontba Ausztria, Észtország, Németország, Litvánia és Hollandia a vállalati vezetốk tevékenységére irányadó magatartási norma meghatározásakor. (Ezzel párhuzamosan megjegyezném, hogy Bulgária, a Cseh Köztársaság, Finnország, Írország, Olaszország, Lettország, Málta, Románia, Szlovákia és Spanyolország jogi szabályozása alapvetően részvényesközpontú megközelítést alkalmaz.) (Study on Directors Duties and Liability, 2013:66-74; Halász, 2016:698-707).

Ausztriában a vállalati vezetốk tevékenységére irányadó fontos szabályozást tartalmaz az osztrák részvénytörvény, az Aktiengesetz 70. § (1) bekezdése. E szerint az igazgatóságnak a társaságot saját felelôsségére (és saját belátása szerint) kell vezetnie oly módon, ahogy azt a társaság érdeke (és jóléte) megköveteli, figyelembe véve a részvényesek, a munkavállalók és a köz érdekét. Ez alapján látható, hogy az osztrák részvénytársaságok igazgatóinak kötelességük teljesítése során elsôsorban a társaság legjobb érdekében kell eljárniuk. Ugyanakkor figyelembe kell venniük a részvényesek, a munkavállalók és a köz érdekét. A társaság érdekét elsôsorban a társaság alapszabálya, illetve az abban foglalt célok határozzák meg. Látható továbbá, hogy az osztrák szabályozás nem nevesíti külön a hitelezôket. Azonban az Aktiengesetz számos hitelezôvédelmi szabályát látva feltételezhetô, hogy a hitelezôk érdekét is tekintetbe kell venni. Fentiek alapján pedig az osztrák társaságok igazgatóinak egy stakeholder szemléletú, azaz az érdekeltek szélesebb körét figyelembe vevố megközelítést kell alkalmazniuk a társaság jólétének elômozdítása során (Fritzberg, 2013:13-14).

Észtországban a társasági jogi szabályozás alapján a társaság nem részvényesorientált, hanem inkább az érdekeltek szélesebb körét veszi figyelembe (stakeholder központú megközelítés). Az igazgatók bizalmi kötelezettsége nem a részvényesek irá- 
nyában áll fenn, hanem a társaságot (mint jogi személyt) kell szolgálniuk, és annak érdekeltjeit (Laidvee, 2013:242).

Németországban az igazgatók alapvetôen a társasággal szemben tartoznak kötelezettségekkel. Ez világosan kitúnik a német részvénytörvény, az Aktiengesetz 93. § (2) bekezdéséból. A kötelességüket megszegó igazgatósági tagok ugyanis egyetemlegesen felelnek a társaság irányába az ezzel okozott károkért. ${ }^{12}$ Németországban az igazgatóknak a társaság érdekét kell védeniük és előmozdítaniuk. Ugyanakkor a társaság érdeke fogalom sokrétú a német társasági jogban. Az igazgatóknak ki kell egyensúlyozniuk azon különböző érdekeket, melyek a társaság érdekét (Unternehmensinteresse) alkotják. Ennek során pedig jellemzóen az ún. praktikus konkordancia, praktikus összhang elvét (Praktische Konkordanz) alkalmazzák, mely Németországban egyébként alkotmányjogi gyökerekkel rendelkezik. Németországban a társaság érdeke egyenértékúnek tekinthetô a „társaság jólétével” (Wohl der Gesellschaft), mely több helyen is visszaköszön a német társasági jogban. Az Aktiengesetz például a 93. § (1) bekezdésében rögzíti, hogy az üzleti tevékenység vezetése során az igazgatóság tagjainak egy rendes és lelkiismeretes üzletvezetô gondosságával kell eljárniuk. Nem tekinthető azonban kötelezettségszegésnek, ha az üzleti döntés meghozatalakor észszerú indokkal feltételezhették, hogy megfelelő információ alapján a „társaság jóléte” érdekében (zum Wohle der Gesellschaft) járnak el. ${ }^{13} \mathrm{~A}$ társaság érdeke fogalom szintén visszaköszön a német vállalatfelvásárlási törvény, a Wertpapiererwerbs- und Übernahmegesetz 3. § (3) bekezdésében. ${ }^{14}$ E szerint - vállalatfelvásárlási helyzetben is - a céltársaság igazgatóságának és felügyeloobizottságának a céltársaság érdekében kell eljárnia. ${ }^{15}$ A német megközelítést így a következôképpen lehet összefoglalni: az igazgatók nem kötelesek csak a részvényesek érdekében eljárni, egészen addig, amíg biztosítják a társaság hosszú távú nyereségességét. A német jogirodalomban megtalálhatók azon álláspontok, melyek szerint az igazgatóknak figyelembe kell venniük az egyéb érdekeltek érdekeit, míg más megközelítések a részvényesi érdekek elsôdlegességét hangsúlyozzák (Klappstein, 2013:332-333).

Litvániában a társasági törvény alapján egy társaság ügyvezetô testületének csak a „társaság és részvényesei javára” kell eljárnia, illetve szintén meg kell felelnie a vonatkozó jogszabályi elơírásoknak és a társaság alapszabályának. Az ügyvezetô testületnek továbbá meg kell felelnie a közgyúlés döntéseinek is. Ez arra utal, hogy a részvényesek kötelezô erejû útmutatásokat adhatnak a társaság menedzsereinek. Ugyanakkor a Litván Legfelsôbb Bíróság rávilágított arra, hogy ez a rendelkezés nem menti fel az ügyvezetô testületeket azon kötelezettségük alól, hogy a társaság érdekében járjanak el. A Litván Legfelsôbb Bíróság felismerte, hogy a részvényesek érdekei és a társaság érdekei különbözhetnek bizonyos helyzetekben. Ezzel kapcsolatban pedig úgy döntött, hogy a társaság ügyvezetô testületeinek nem szabad eleget tenniük a részvényesek utasításainak, ha ez ellentétes lenne a társaság érdekével. Továbbá Litvániában a polgári törvénykönyv alapján a társaság szervezetének (igazgatóság, felügyelőbizottság) tagjainak a társasághoz kell lojálisnak lenniük. A lojalitás pontos jelentését ugyanakkor nem fejti ki a litván polgári törvénykönyv, így a bíróságokra, illetve bizonyos mértékben a jogi szakirodalomra maradt e kötelezettség pontos terjedelmének értelmezése. Ezzel kapcsolatban a litván jogirodalom a társasághoz való lojalitás kötelezettségét leginkább úgy 
Halász Vendel: A stakeholder elmélet és megjelenése az európai államok...

értelmezte, mint kötelezettséget a társaság, annak részvényesei, hitelezôi, munkavállalói és a köz érdekében és javára való cselekvésre (Filonovas, 2013:523-524, 529-530).

Hollandiában a társasági jogban alapvetően a stakeholder szemlélet érvényesül, azaz a részvényesekén túlmutató egyéb érdekeket is figyelembe veszik (De Beurs, 2013:612-613). Általánosan elmondható, hogy Hollandiában egy igazgatónak a társaság érdekében kell eljárnia. Mivel pedig a holland társasági jog az egyéb érdekeltek érdekeit is figyelembe vevő (stakeholder) modellt követi, ezért ez nem csak a részvényesi érdeket foglalja magában. Az uralkodó elmélet szerint a társaság érdeke az illetô érdekeltek érdekeinek mérlegelését kívánja meg. Ilyen érdekeltek a részvényesek, a munkavállalók és a hitelezók. A stakeholder elmélet alkalmazása miatt az igazgatóknak nemcsak megfontolni fontos az érdekeltek összes különbözó érdekeit, hanem ezt be is kell építeniük a döntéshozatali folyamatukba. A holland jogi szabályozás ugyanakkor nem ad útmutatást az igazgatóknak abban, miként mérlegeljék a különböző érdekeket (De Beurs, 2013:621). A holland vállalatirányítási kódex (The revised Dutch Corporate Governance Code 2016) is egyértelmúen ezt a szemléletet tartja követendônek. A kódex 1. fejezete Hosszú távú értékteremtés (Long-term Value Creation) címszó alatt kifejti, hogy az igazgatóság felelôs a társaság (és kapcsolt vállalkozásai) folytonosságáért. Az igazgatóság a hosszú távú értékteremtésre fókuszál a társaság számára, és tekintetbe veszi az érdekeltek (stakeholder) érdekeit, melyek relevánsak ebben az öszszefüggésben. A felügyelőbizottság pedig felügyeli az igazgatóságot ebben (Corporate Governance Code Monitoring Committee, 2016).

\section{A STAKEHOLdER ELMÉLET MEGJELENÉSE}

A MUNKAVÁlLALÓI KÉPVISELET INTÉZMÉNYÉBEN

Németországban a nyilvánosan múködô részvénytársaságok esetében az egyéb érdekelteknek (kiemelten pedig a munkavállalóknak) közvetlen szerepe van a társaságirányításban (Kecskés-Ferencz, 2017:125). A német felelôs társaságirányítási rendszer, illetve az abban rejlô stabilitás továbbá abból kiindulva is számot tarthat az érdeklốdésünkre, hogy az a legutóbbi tapasztalatok fényében jobban ellenáll a pénzügyi válságoknak, mint a legtöbb más fejlett gazdaság (Jackson, 2011:353).

A munkavállalói képviselet gyökerei a német jogban a 20. század elsố felébe nyúlnak vissza, mikor hangsúlyos szerepet töltött be a társadalmi konfliktusok kezelésében. Bár jelentôsége csökkent, számos pozitív hatását napjainkig megtartotta, így becsatornázza a társadalmi konfliktusokat, csökkenti a sztrájkok valószínúségét, és az ellenséges vállalatfelvásárlásokkal szemben is növeli a társaságok védettségét (Jungmann, 2006: 455; Kecskés, 2011:280-281). További jelentôs hatása, hogy a társaságirányításban való munkavállalói részvétel elômozdíthatja a koncentrált tulajdonosi struktúra létrejöttét és fennmaradását. Ha ugyanis a munkavállalók közös erôvel lépnek fel, a tőkének szintén koncentrálódnia kell (Roe, 1999:200, 210-211; Kecskés-Halász, 2013:374-376, 377-378).

A német felelôs társaságirányítási rendszer fontos sajátossága, hogy közvetlenül beépíti az egyéb érdekeltek érdekeit a társaságok döntéshozatali rendszerébe. Ugyanis 
a munkavállalói képviselet intézményével egy rendkívül fontos, az egyéb érdekeltek körébe tartozó csoport, a munkavállalók kapnak beleszólást a társaság döntéshozatalába. A német társaságokban a munkavállalói küldöttek részt vesznek a felügyelôbizottságok munkájában. Ennek során pedig - mint felügyelőbizottsági tagoknak - például joguk van felvilágosítást kérni a társaságot érintő kérdésekben az ügyvezetéstől, kifejteni, illetve konzultálni az álláspontjukkal kapcsolatban, valamint a felügyelőbizottság határozathozatalában részt venni. A német részvénytörvény, az Aktiengesetz továbbá lehetôséget biztosít az ügydöntô felügyelóbizottságok alkalmazására, mely esetben a munkavállalói képviselők tulajdonképpen közvetlen beleszólást kaphatnak az üzleti döntések meghozatalába. A társaságok alapszabálya ugyanis meghatározhat olyan üzleti döntéseket, melyeket csak a felügyelóbizottság hozzájárulásával lehet meghozni (Jackson, 2011:367-368). ${ }^{16}$

A munkavállalói képviselet intézményét az 1976-ban elfogadott Mitbestimmungsgesetz rendelkezései szabályozzák Németországban (Davies, 2001:435-456). A Mitbestimmungsgesetz a 7. szakaszában szabályozza a felügyelőbizottság összetételét. Ez alapján - fôszabályként - 10000 munkavállalóig a részvényesek („hányadtulajdonosok”) és a munkavállalók egyaránt 6-6 tagot delegálnak a társaságok felügyelóbizottságaiba. 100 00-nél több, de 20 000-nél kevesebb munkavállaló esetén a felügyelőbizottságok a részvényesek és a munkavállalók által delegált 8-8 tagból, 20000 munkavállaló felett pedig 10-10 tagból állnak (Jungmann, 2006:455; Kecskés, 2011:280-281). ${ }^{17}$ A Mitbestimmungsgesetz 7. szakasz (2) bekezdése továbbá részletezi, hogy a felügyelôbizottságokban tevékenykedô munkavállalói képviselôk milyen arányban kerülnek ki a társaság munkavállalói, illetve a szakszervezetek képviselôi közül. Látható, hogy ez a modell korlátozott, de kifejezett befolyást biztosít az egyéb érdekeltek körébe tartozó munkavállalói csoportnak.

Számos más társasági jogi rendszerben is (különösen a kontinentális Európában) engednek beleszólást a munkavállalóknak a társaság irányításába a felügyelóbizottságban való részvétel útján. Így például hasonló rendszert alkalmaz Hollandia. Óvatosabb, de szintén jelentôs a munkavállalói részvétel jelenléte Ausztriában, a Cseh Köztársaságban, Szlovéniában, Szlovákiában, Magyarországon, Luxemburgban, Dániában, Svédországban és Finnországban (Gelter, 2009:168-169; Kecskés, 2011:280_ 281; Study on Directors Duties and Liability, 2013:9-10).

Megállapítható, hogy a vállalati vezetôk tevékenységére irányadó szabályokban a stakeholder megközelítést érvényesítő öt uniós tagállam közül három (nevezetesen Ausztria, Németország és Hollandia) biztosítja a munkavállalói képviseletet is. Szintén látható, hogy a munkavállalói képviselet intézményét alkalmazó uniós tagállamok közül a vállalati vezetôk tevékenységére irányadó szabályokban inkább a részvényesi érdekek által orientált a Cseh Köztársaság, Finnország és Szlovákia (Study on Directors Duties and Liability, 2013:66-74; Halász, 2016:698-707). Így e két jogi megoldás között - e szerint - nem áll fenn egyértelmú kapcsolat. A vállalati vezetôk tevékenységével kapcsolatban a részvényesi érdekek kizárólagosságát hangsúlyozó államokban is megjelenhet a munkavállalói képviselet intézménye. Ugyanakkor nem feltétlenül jelenik meg a munkavállalói képviselet intézménye abban az esetben, ha a vállalati 
Halász Vendel: A stakeholder elmélet és megjelenése az európai államok...

vezetôk tevékenységével kapcsolatban a stakeholder megközelítés érvényesül. Ezt mutatja Észtország és Litvánia példája (Study on Directors Duties and Liability, 2013:9; Filonovas, 2013:523).

Ezzel párhuzamosan szükséges kiemelnünk, hogy az angolszász államok (így az Egyesült Államok és az Egyesült Királyság társaságirányítási berendezkedése) nem biztosítják a munkavállalók beleszólását a társaságirányításba, a munkavállalói képviselet rendszere nem érvényesül (Kecskés, 2011:274). Az Európai Unióban pedig a munkavállalói képviselet harmonizálására irányuló törekvések ez idáig nem vezettek eredményre (Halász, 2015:19-24).

\section{ZÁRÓGONDOLATOK}

Jelen tanulmány több olyan példát igyekezett bemutatni az európai államok társasági jogi megoldásai közül, melyek már jelenleg is a stakeholder szemléletet követik, és az érdekeltek szélesebb körének figyelembevétele irányába mutatnak a társaságok múködésének területén. A bemutatott példák a vállalati vezetôk tevékenységére irányadó szabályokra és a munkavállalói képviselet jogintézményére fókuszálnak. A vállalati vezetơk tevékenységére irányadó szabályok kapcsán az Európai Unió öt tagállama is a stakeholder szemléletet követi, nevezetesen Ausztria, Észtország, Németország, Litvánia és Hollandia. Ezen államokat áttekintve megállapítható, hogy mind fejlett gazdasággal rendelkezô államok. 2016-ban az egy főre jutó GDP Ausztriában 44 176,5 USD, Németországban 41 936,1 USD, míg Hollandiában 45 294,8 USD volt a Világbank adatai alapján. ${ }^{18} \mathrm{Ez}$ pedig belépést biztosít számukra a világ húsz legmagasabb egy fôre jutó GDP-értékével rendelkezô állama közé, mely tekintélyes eredmény. Ezen államoknak a társadalmi fejlettséget összetettebben leképezô úgynevezett emberi fejlettségi indexe (HDI, human development index) is meglehetôsen magas. Az Egyesült Nemzetek Szervezete által közzétett világrangsorban 2015-ben Ausztria a 24. helyet, Németország a 4. helyet, míg Hollandia a 7. helyet szerezte meg. ${ }^{19}$ Észtország és Litvánia - mint egykori szovjet tagköztársaságok - a függetlenné válásuk óta természetesen bizonyos hátrányt voltak kénytelenek ledolgozni a gazdasági fejlettség tekintetében. Ugyanakkor Észtország egy fớre esô GDP-je 17 574,7 USD, míg Litvániáé 14 879,7 USD volt 2016-ban. ${ }^{20} \mathrm{Ez}$ pedig már majdnem eléri például a portugál GDP-t (19 813,3 USD). Észtország emberi fejlettségi indexe a világon a 30., míg Litvániáé a 37. ${ }^{21}$ Ezzel az elemzéssel azt törekedtem illusztrálni, hogy a stakeholder szemlélet álláspontom szerint nem áll ellentétben a gazdasági eredményekkel, sokkal inkább a harmonikus növekedés alapjait biztosíthatja a társasági szférában. A munkavállalói képviselet intézménye - hatékonyan alkalmazva - pedig szintén hozzájárulhat ehhez. Mivel pedig a stakeholder szemlélet több, jól múködô és nagy múltú szabad piacgazdaságban is jelen van, így véleményem szerint nem jelentheti a kapitalista gazdasági rendszer „kikezdését”. Sokkal inkább a fenntarthatóságának biztosítását szolgálja. Ugyanis a kapitalizmus megvédésének egyetlen módja azon vezetésen keresztül lehetséges, mely elfogadja a társadalmi felelôsséget, és megfelel az emberek nagy többsége józan igényeinek. ${ }^{22}$ 


\section{Polgári Szemle · 13. évfolyam 4-6. szám}

\section{JEGYZETEK} School of Economics professzora, illetve a London School of Economics (LSE) International Inequalities Institute professzora.

3 Az Egyesült Államokban - a modern gazdasági társasági formák kialakulásakor - hagyományosan olyan társaságokat jegyeztek be, melyek valamilyen, a társadalom érdekében álló tevékenységet végeztek. Így például biztosították a közlekedést vagy a vízellátást, banki vagy biztosítási tevékenységet fejtettek ki. Bizonyos nézôpontból pedig e társaságoknak a korlátolt felelôsség megadása egy bizonyos „társadalmi támogatás”, amiért cserébe a társadalom társadalmilag felelôs magatartást várhat el. Lásd Springer, 1999:102-103.

4 A Dartmouth College v. Woodward (17 U. S. 518, 1819) esetre hivatkozik, lásd www.americanbar.org/ groups/public_education/initiatives_awards/students_in_action/dartmouth.html.

5 Chief Justice John Marshall (1755-1835) az Amerikai Egyesült Államok Legfelsốbb Bíróságának vezetô bírája (Chief Justice of the Supreme Court) 1801-1835-ig. Máig a leghosszabban hivatalban lévố személy is ebben a pozícióban.

6 Steven M. H. Wallman a Securities and Exchange Commission biztosa 1994-1997-ig. Ezt megelôzôen a Covington \& Burling jogi iroda partnere.

7 R. Edward Freeman a University of Virginia Darden School of Business professzora.

8 Max B. E. Clarkson (1922-1989) akadémiai pályáját tekintve a University of Toronto, Faculty of Management dékánja (1975-1980), ezt követôen 1988-ig professzora, majd professor emeritusa. 1989-ben megalapította a Centre for Corporate Social Performance and Ethics intézetet. Úttörô munkát végzett a társasági értékek bemutatása és az üzleti etika területén. Nevét ôrzik az egyéb érdekeltek érdekeinek figyelembevételével kapcsolatos alapelveket tartalmazó ún. Clarkson-elvek (The Clarkson Principles of Stakeholder Management). www.cauxroundtable.org/index.cfm?menuid=61.

9 Archie B. Carroll a University of Georgia professor emeritusa.

10 Robert Hugh Gray a University of St. Andrews professzora.

11 Tibor R. Machan (1939-2016) magyar származású amerikai filozófus. Az Auburn University filozófia tanszékének egykori professor emeritusa, a Chapman University egykori professzora.

12 Lásd Aktiengesetz vom 6. September 1965 (BGBl. I S. 1089), das zuletzt durch Artikel 9 des Gesetzes vom 17. Juli 2017 (BGBl. I S. 2446) geändert worden ist, 93. § (2), www.gesetze-im-internet.de/aktg/ index.html\#BJNR010890965BJNE010809360.

13 Aktiengesetz vom 6. September 1965 (BGBl. I S. 1089), das zuletzt durch Artikel 9 des Gesetzes vom 17. Juli 2017 (BGBl. I S. 2446) geändert worden ist 93. § (1), www.gesetze-im-internet.de/aktg/index.html \#BJNR010890965BJNE010809360.

14 Wertpapiererwerbs- und Übernahmegesetz vom 20. Dezember 2001 (BGBl. I S. 3822), das durch Artikel 9 des Gesetzes vom 23. Juni 2017 (BGBl. I S. 1693) geändert worden ist, www.gesetze-im-internet.de/ wp_g/.

15 Wertpapiererwerbs- und Übernahmegesetz (WpÜG) § 3 Allgemeine Grundsätze, www.gesetze-im-internet.de/wp_g/_3.html.

16 Lásd még Aktiengesetz vom 6. September 1965 (BGBl. I S. 1089), das zuletzt durch Artikel 9 des Gesetzes vom 17. Juli 2017 (BGBl. I S. 2446) geändert worden ist $§ 111$ Aufgaben und Rechte des Aufsichtsrats.

17 Lásd még Gesetz über die Mitbestimmung der Arbeitnehmer (Mitbestimmungsgesetz-MitbestG). Mitbestimmungsgesetz vom 4. Mai 1976 (BGBl. I S. 1153), das zuletzt durch Artikel 7 des Gesetzes vom 24. April 2015 (BGBl. I S. 642) geändert worden ist, 7. § (1), www.gesetze-im-internet.de/mitbestg/ BJNR011530976.html.

18 Lásd a Világbank adatait: GDP per capita (current US\$), https://data.worldbank.org/indicator/ NY.GDP.PCAP.CD?name_desc $=$ false.

19 Lásd az Egyesült Nemzetek Szervezete által közölt adatokat: Human Development Data (1990-2015), http://hdr.undp.org/en/data. 


\section{Halász Vendel: A stakeholder elmélet és megjelenése az európai államok...}

20 Lásd a Világbank adatait: GDP per capita (current US\$), https://data.worldbank.org/indicator/ NY.GDP.PCAP.CD?year_high_desc=false.

21 Lásd az Egyesült Nemzetek Szervezete által közölt adatokat: Human Development Data (1990-2015), http:/ /hdr.undp.org/en/data.

22 Ahogy azt Wallace Brett Donham (1877-1954), az üzleti adminisztráció professzora és a Harvard Business School egykori dékánja megfogalmazta Business Adrift címú múvében. Lásd errôl Dodd, 1932:11551156.

\section{FELHASZNÁLT IRODALOM}

Bujtár Zsolt (2016): Az árnyékbankrendszer és az értékpapírosítás az Egyesült Államokban. Controller Info, 4. évf., 3. sz., 37-41.

Caux Round Table (2002): The Clarkson Principles of Stakeholder Management. Principle 1., www.cauxroundtable.org/index.cfm?menuid=61.

Corporate Governance Code Monitoring Committee (2016): The Revised Dutch Corporate Governance Code 2016. Unofficial translation, www.mccg.nl/?page $=3779$.

Davies, Paul L. (2001): Board Structure in the UK and Germany: Convergence or Continuing Divergence? International and Comparative Corporate Law Journal, Vol. 2, No. 4, http://dx.doi.org/10.2139/ ssrn.262959.

De Beurs, Sybren (2013): Directors' Duties and Liability in the Netherlands. In: Annex to Study on Director's Duties and Liability prepared for the European Commission DG Markt. Eds. Carsten Gerner-Beuerle et al., http://ec.europa.eu/internal_market/company/docs/board/2013-study-reports_en.pdf.

Dodd, E. Merrick (1932): For Whom Are Corporate Managers Trustees? Harvard Law Review, Vol. 45, No. 7, https://doi.org/10.2307/1331697.

Filonovas, Eugenijus (2013): Directors' Duties and Liability in Lithuania. In: Annex to Study on Director's Duties and Liability prepared for the European Commission DG Markt. Eds. Carsten Gerner-Beuerle et al., http:/ /ec.europa.eu/internal_market/company/docs/board/2013-study-reports_en.pdf.

Friedman, Milton (1970): The Social Responsibility of Business Is to Increase Its Profits. The New York Times Magazine, September 13.

Fritzberg, Nora (2013): Directors' Duties and Liablity in Austria. In: Annex to Study on Director's Duties and Liability prepared for the European Commission DG Markt. Eds. Carsten Gerner-Beuerle et al., http:// ec.europa.eu/internal_market/company/docs/board/2013-study-reports_en.pdf.

Gelter, Martin (2009): Dark Side of Shareholder Influence: Managerial Autonomy and Stakeholder Orientation in Comparative Corporate Governance. Harvard International Law Journal, Vol. 50, No. 1.

Gray, Rob - Owen, Dave - Adams, Carol (1996): Accounting and Accountability: Changes and Challenges in Corporate Social and Environmental Reporting. Prentice Hall, Upper Saddle River.

Greenfield, Kent (2008a): Defending Stakeholder Governance. Case Western Reserve Law Review, Vol. 58, No. 4, 1043-1065.

Greenfield, Kent (2008b): Reclaiming Corporate Law in a New Gilded Age. Harvard Law and Policy Review, Vol. 2, No. 1, 1-32.

Halász Vendel (2015): Érdekek és értékek az Európai Unió és az Egyesült Államok vállalatfelvásárlási szabályozásában. Kézirat. Doktori értekezés, Pécs, 19-24., http://pea.lib.pte.hu/bitstream/handle/pea/15664/ halasz-vendel-phd-2016.pdf? sequence=1\&isAllowed=y.

Halász Vendel (2016): A „társaság érdeke”: a vállalati vezetôk tevékenységére irányadó szabályokról Európában és Amerikában. Magyar Jog, 63. évf., 12. sz., 698-707.

Hansmann, Henry - Kraakman, Reinier (2001): The End of History for Corporate Law. Georgetown Law Journal, Vol. 89, No. 2, 439-468.

HVG.hu (2017): A vesztünkbe rohanunk: 15000 tudós írt egy nyílt levelet, és most már végre komolyan kellene vennünk ôket. $H V G . h u$, http://hvg.hu/tudomany/20171114_tudosok_nyilt_levele_az_emerisegnek_kornyezetvedelem_fold_globalis_felmelegedes_klimavaltozas_masodik_figyelmeztetes. 
Ireland, Paddy (2005): Shareholder Primacy and the Distribution of Wealth. Modern Law Review, Vol. 68, No. 1, 49-81, https://doi.org/10.1111/j.1468-2230.2005.00528.x.

Jackson, Katharine V. (2011): Towards a Stakeholder-Shareholder Theory of Corporate Governance: A Comparative Analysis. Hastings Business Law Journal, Vol. 7, No. 2, 309-392.

Jowit, Juliette (2010): World's top firms cause $\$ 2.2$ tn of environmental damage, report estimates. The Guardian, 18 February, www.theguardian.com/environment/2010/feb/18/worlds-top-firms-environmentaldamage.

Jungmann, Carsten (2006): The Effectiveness of Corporate Governance in One-Tier and Two-Tier Board Systems. European Company and Financial Law Review, Vol. 3, No. 4, 426-474, https://doi.org/10.1515/ ECFR.2006.019.

Keay, Andrew (2010): Stakeholder Theory in Corporate Law: Has It Got What It Takes? Richmond Journal of Global Law E B Business, Vol. 9, No. 3, 249-300, https://doi.org/10.2139/ssrn.1531065.

Kecskés András (2008): A kereskedelmi jog régi professzorai Pécsen (Bozóky Géza és Rudolf Lóránt). In: Pécsi jogászprofesszorok emlékezete (1923-2008). Szerk. Kajtár István, Pécsi Tudományegyetem, Pécs.

Kecskés, András (2010): The Legal Theory of Stakeholder Protection. Jura, 16. évf., 1. sz., 67-76.

Kecskés András (2011): Felelós társaságirányítás (Corporate Governance). HVG-ORAC, Budapest.

Kecskés, András (2016): The Sarbanes-Oxley Act from a Legislative Viewpoint. Theory and Practice of Legislation, Vol. 4, No. 1, https://doi.org/10.1080/20508840.2016.1148315.

Kecskés András - Ferencz Barnabás (2017): Szirénhangok a Rajnán. Iustum Aequum Salutare, 13. évf., 1. sz., $107-125$.

Kecskés, András - Halász, Vendel (2013): Stock Corporations. A Guide to Initial Public Offerings, Corporate Governance and Hostile Takeovers. HVG-ORAC - Lexis Nexis, Budapest-Wien.

Klappstein, Verena (2013): Directors' Duties and Liability in Germany. In: Annex to Study on Director's Duties and Liability prepared for the European Commission DG Markt. Eds. Carsten Gerner-Beuerle et al., http:// ec.europa.eu/internal_market/company/docs/board/2013-study-reports_en.pdf.

Laidvee, Nele (2013): Directors' Duties and Liability in Estonia. In: Annex to Study on Director's Duties and Liability prepared for the European Commission DG Markt. Eds. Carsten Gerner-Beuerle et al., http:// ec.europa.eu/internal_market/company/docs/board/2013-study-reports_en.pdf.

Liao, Carol (2012): Corporate Governance Reform for the 21st Century: A Critical Reassessment of the Shareholder Primacy Model. Ottawa Law Review, Vol. 43, No. 2.

Machan, Tibor R. (2017): Stakeholder vs. Shareholder Debate: Some Skeptical Reflections. Contemporary Readings in Law and Social Justice, Vol. 9, No. 1, 7-13, https://doi.org/10.22381/CRLSJ9120171.

Millon, David (2013): Shareholder Primacy in the Classroom After the Financial Crisis. Journal of Business Ẽ Technology Law, Vol. 8, No. 1, 191-195.

Papp Tekla (2009): Corporate Governance - Társaságirányítási rendszerek. In: Acta Conventus de Iure Civili, Tomus X. Szerk. Papp Tekla, Lectum Kiadó, Szeged, 185-200.

Piketty, Thomas (2015): A tôke a 21. században. Kossuth Kiadó, Budapest.

Rahim, Mia Mahmudur (2011): The „Stakeholder Approach” to Corporate Governance and Regulation: An Assessment. Macquarie Journal of Business Law, Vol. 8, 304-325.

Roe, Mark J. (1999): German Codetermination and German Securities Markets. The Columbia Journal of European Law, Vol. 5, No. 2, 199-212, http://dx.doi.org/10.2139/ssrn.10578.

Sprague, Robert, J. D. - Lyttle, Aaron J. (2010): Shareholder Primacy and the Business Judgment Rule: Arguments for Expanded Corporate Democracy. Stanford Journal of Law, Vol. 16, No. 1, https://doi. org/10.2139/ssrn.1647002.

Springer, Jonathan D. (1999): Corporate Constituency Statutes: Hollow Hopes and False Fears. Annual Survey of American Law, Vol. 85, 85-124.

Stout, Lynn A. (2002): Bad and Not-so-Bad Arguments for Shareholder Primacy. Southern California Law Review, Vol. 75, No. 5, http://dx.doi.org/10.2139/ssrn.331464.

Stout, Lynn A. (2013): On the Rise of Shareholder Primacy, Signs of Its Fall, and the Return of Managerialism (in the Closet). Seattle University Law Review, Vol. 36, No. 2, 1169-1185. 
Halász Vendel: A stakeholder elmélet és megjelenése az európai államok...

Study on Directors Duties and Liability (2013): prepared for the European Commission DG by Carsten Gerner-Beuerle, Philipp Paech, Edmund Philipp Schuster, London, http://ec.europa.eu/internal_market/ company/docs/board/2013-study-analysis_en.pdf.

Velasco, Julian (2010): Shareholder Ownership and Primacy. University of Illinois Law Review, No. 3, 897956, https://doi.org/10.2139/ssrn.1274244.

Wallman, Steven M. H. (1991): The Proper Interpretation of Corporate Constituency Statutes and Formulation of Director Duties. Stetson Law Review, Vol. 21, No. 1.

Zhao, Jingchen (2014): The Curious Case of Stakeholder Theory: Calling for a More Realistic Theory. International Trade and Business Law Review, Vol. 17, No. 1. 